\title{
圧電セラミックスを用いた機械的ダンパー
}

\author{
内野研二・石井孝明 \\ （上智大学理工学部物理学科, 102 東京都千代田区紀尾井町 7-1)
}

\section{Mechanical Damper Using Piezoelectric Ceramics}

\author{
Kenji UCHINO and Takaaki ISHII \\ (Department of Physics, Faculty of Science and Technology, Sophia University, ) \\ 7-1, Kioi-cho, Chiyoda-ku, Tokyo 102
}

\begin{abstract}
A piezoelectric ceramic mechanical damper with a controllable damping factor has been developed. Mechanical vibration energy is transformed through the piezoelectric effect into electrical energy which is dissipated through an external resistance. A significant variation in damping factor is realized when the external resistance is changed.
\end{abstract}

[Received March 15, 1988; Accepted April 26, 1988]

Key-words : Mechanical damper, Piezoelectric ceramics

\section{1. 緒言}

機械や素子の振動, 騒音を防止することは大切であり, 超精密加工機，超精密位置決め機構等の防振には多くの 注意が払われている．防振対策として最も効果のある方 法は，振動源を断つことであるが，完全に振動の発生を 押え込むことは不可能で，他の方法を併用することが一 般になされている，それらには，弾性懸架による防振や 振動を熱にして吸収する方法がある，後者の例で，振動 を熱に変える機構を材料自身に持たせたものとして, 制 振鋼（トランカロイ）が既に知られている1)。この物質 は応力と歪みとの関係に履歴現象があるので, 振動する たびに熱としてエネルギーを消費するために振動がすば やく減衰する，しかしながら，このような普通の減衰器 (ダンパー) では, 例えば, ある時は防振し，またある 時は振動させたいというときには不便である.それには, ダンパーにおいて，ダンピングの時定数を可変にするこ とが必要である.

著者らは既に, 圧電アクチュエーター素子のパルス駆 動において，オーバーシュートやリンギングの防止につ いて, 適当な条件で電界を印加すればこれらの問題は避 けられることを報告した ${ }^{21}$. 本研究では, このパルス駆 動の一つの応用的な流れとして, 逆の効果を利用し, 機 械的ダンパーの試作を行った．外部から電界をかけるこ とを行わず，外乱によって生じた振動を，圧電セラミッ クスの圧電効果を利用して電気的エネルギーに変換し, それを抵抗で熱エネルギーとして消費することで振動の 減衰をさせることを行った。 ダンピングの時定数は, セ ラミックスに接続する抵抗を変化させることで電気的に 行うことができる.

\section{2. 原理}

ダンパーの制振の原理を, 圧電セラミックス単板の横 効果で説明する．圧電セラミックス単板（図１（a)）に 外力が加わった場合, 圧電効果により電荷が発生する (図 1(b)). だから外力が取り除かれた後の残留振動で,

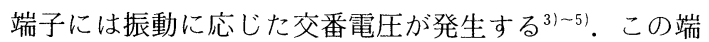
子間に抵抗を接続し，現れた電荷を流して熱として消費 する（図 1 (c)). 接続する抵抗の值が極端に大きなも のであったなら, 回路にはほとんど電流が流れずエネル

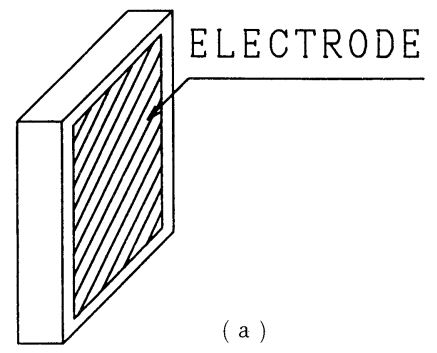

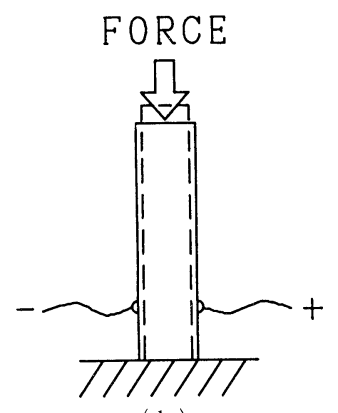

(b)

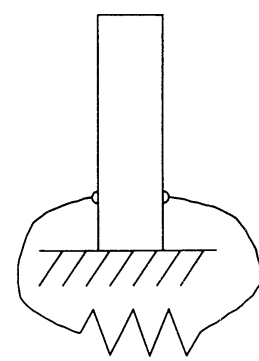

(c)
Fig. 1 (a) Structure of single plate, (b) piezoelectric effect, and (c) external resistor connected. 
ギーの消費は少ない，また，抵抗の值が極端に小さいも のでは電流はたくさん流れるが，抵抗が小さいためこの 場合もエネルギーの消費は少ない，よって，どちらの場 合も振動はなかなか収まらない，しかし，どこかにエネ ルギー消費が最大になる最適な抵抗值のあることが予想 される，発生するジュール熱が最大になれば，それは即 振動エネルギー消費最大となり, 最も制振効果が大きく なると考えられる。

共振点近傍において压電セラミックスに抵抗を接続し たときの等価回路を図 2 に示す．圧電セラミックスの振 動によって発生する交番電圧 (角周波数 $\omega$ ) は仮想的に 外部電源として $V(t)$ とおき, それが外付けした抵抗 の両端にかかっている．回路のインピーダンス $Z$ は次 のように表される.

$$
Z=R+\frac{1}{i \omega C_{\mathrm{d}}+\frac{1}{R^{\prime}+i \omega L+\frac{1}{i \omega C_{\mathrm{p}}}}}
$$

共振周波数では, $\omega^{2}=1 / L C_{\mathrm{p}}$ とおいて次を得る.

$$
\begin{aligned}
& Z=R+\frac{1}{\frac{1}{R^{\prime}}+i \omega C_{\mathrm{d}}} \\
& |Z|^{2}=\left\{R+\frac{R^{\prime}}{1+\left(\omega C_{\mathrm{d}} R^{\prime}\right)^{2}}\right\}^{2}+\left\{\frac{\omega C_{\mathrm{d}} R^{\prime 2}}{1+\left(\omega C_{\mathrm{d}} R^{\prime}\right)^{2}}\right\}^{2}
\end{aligned}
$$

抵抗 $R$ の消費するジュール熱 $W$ は $V=V_{0} \cdot R / Z$ に気 をつけると，

$$
W=\frac{V_{0}^{2} R}{\left\{R+\frac{R^{\prime}}{1+\left(\omega C_{\mathrm{d}} R^{\prime}\right)^{2}}\right\}^{2}+\left\{\frac{\omega C_{\mathrm{d}} R^{\prime 2}}{1+\left(\omega C_{\mathrm{d}} R^{\prime}\right)^{2}}\right\}^{2}}
$$

と表される.

(4) 式が極大值をとるのは,

$$
R=\sqrt{\left\{\frac{R^{\prime}}{1+\left(\omega C_{\mathrm{d}} R^{\prime}\right)^{2}}\right\}^{2}+\left\{\frac{\omega C_{\mathrm{d}} R^{\prime 2}}{1+\left(\omega C_{\mathrm{d}} R^{\prime}\right)^{2}}\right\}^{2}}
$$

の時である.

（5）式を（4）式に代入すると次のようになる.

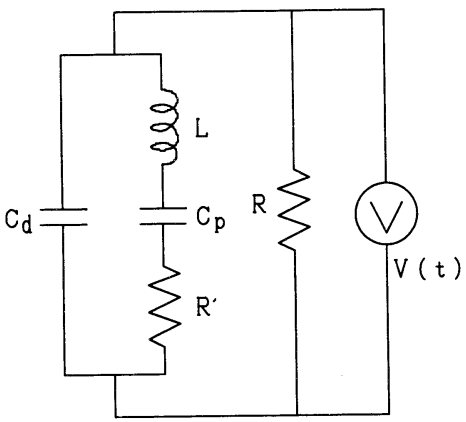

Fig. 2. Equivalent circuit of piezoelectric ceramics with external resistor.

$$
W=\frac{V_{0}^{2}}{\frac{2 R^{\prime}}{\sqrt{1+\left(\omega C_{\mathrm{d}} R^{\prime}\right)}}\left\{1+\frac{1}{\sqrt{1+\left(\omega C_{\mathrm{d}} R^{\prime}\right)}}\right\}}
$$

(5) 式は, 接続抵抗 $R$ をセラミックスのもつインピー ダンスと等しくすれば消費エネルギーが最大になること を示している.そのときの回路全体の抵抗は $2 R$ となり, $R$ の消費エネルギーは誘起された電気的エネルギーの 半分になる.

つまり，抵抗を接続することで振動で誘起された電気 エネルギーを熱エネルギーに変換する効率は最大 $50 \%$ であることがわかった。

\section{3. 実験方法}

振動する物体と圧電セラミック久を組み合わせたもの として代表的なものには, 弾性体の両側に薄い圧電七ラ ミックス板 2 枚を貼りつけた圧電バイモルフ素子がある $(\text { 図 } 3)^{6), 7}$. 本研究ではこのバイモルフを用いて圧電ダ ンパーの実験を行った。

まず実験に使用したバイモルフ 2 種類について, 寸法 と諸定数を表 1 にまとめた。ここに示した寸法は万力で

Table 1. Characteristics of bimorphs.

\begin{tabular}{|c|c|c|}
\hline & BIMORP I & B I YORPH 2 \\
\hline$Q_{H}$ & 30 & 100 \\
\hline$k$ & 0.28 & 0.27 \\
\hline LE N T H [ m m ] & 25 & 37 \\
\hline W I D T H & 16 & 13 \\
\hline TH I C K NE S S & 0.5 & 0.5 \\
\hline $\begin{array}{c}\text { RE S ONA N C E } \\
\text { FRE Q UENC Y }\end{array}$ & $294 \mathrm{~Hz}$ & $193 \mathrm{~Hz}$ \\
\hline
\end{tabular}

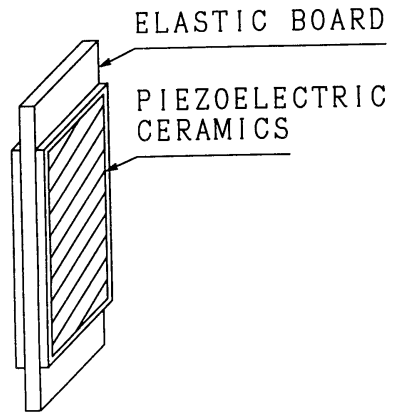

Fig. 3. Construction of bimorph.

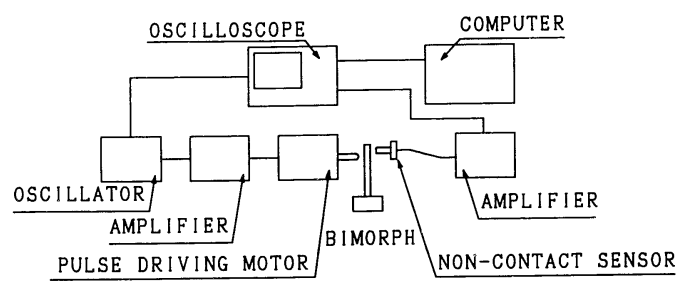

Fig. 4. Mechanical vibration measuring system. 
クランプした部分以外を測ったものである. バイモルフ のアドミッタンス特性及び諸定数の測定は, 万力でクラ ンプして行った. 测定はYHPの 4129 A インピーダン ス・アナライザーを用いて行い, コンピューター処理に よってコール・コール・プロットをとり諸定数の算出を 行っている.実験のブロックダイヤグラムを図 4 に示す. バイモルフに変位を与える外力には, ボイスコイル方式 のパルス駆動モーターを使用している. 発振器の矩形波 出力を増幅してパルス駆動モーターに供給する。モー ターは出力を取り出す軸が前後に変位し, バイモルフを 押したり離したりしている. 離したときに残留振動が起 こる.

残留振動の変位を測定するのは渦電流を利用した非接 触変位センサー（カーマン, SDP-2300）を使用した. センサー出力は増幅され,オシロスコープに記憶される. オシロスコープのトリガー信号は発振器から取り入れて いる.

バイモルフの残留振動の減衰を評価する方法は, 振動 のピーク座標を最小自乗法で近似し, 時定数を求めるこ ととした.

\section{4. 結果及び考察}

\section{1 測定結果}

バイモルフ 1 を用いて行った先端変位振動の測定結果 は図 5 に示したようになった。回路をショートしても オープンにしてもエネルギーの消費は少ないため余り減 衰していないことがわかる. $6.6 \mathrm{k} \Omega$ の抵抗をつないだ ときのセンサー出力で $80 \mathrm{~ms}$ 以降はほとんどノイズ信号 である.

これらの減衰振動の時定数と, 接続した外部抵抗との 関係を図 6 に示した. $8 \mathrm{k} \Omega$ 付近に極小值をとることが
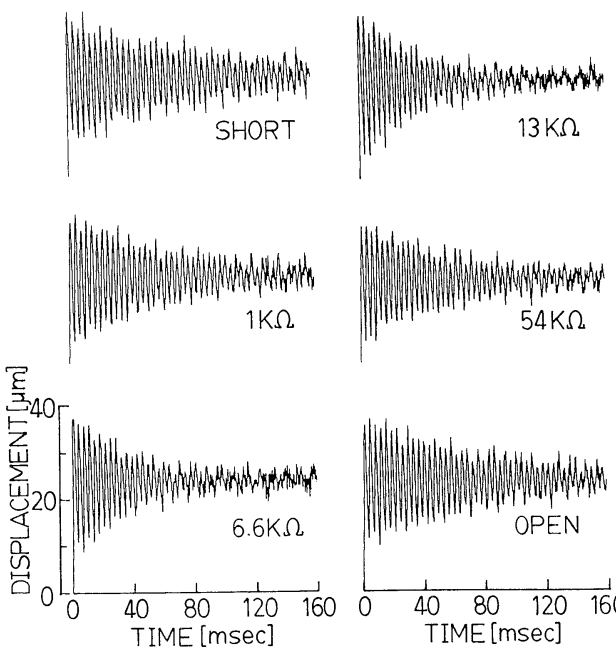

Fig. 5. Change of ringing associated with resistor change.
グラフから読み取れる.

バイモルフ 2 についても同様に測定を行った（図 7, 図 8). $20 \mathrm{k} \Omega$ 付近で極小值を持つことが認められる.

\section{2 原理との対応}

共振周波数の時のバイモルフのインピーダンスを YHP 4192 A で測定するとバイモルフ 1 は約 $8 \mathrm{k} \Omega$, バ イモルフ 2 は約 $20 \mathrm{k} \Omega$ であった.（5）式より, バイモ ルフのインピーダンスと接続した抵抗の值が等しくなっ たときに最大の効果が得られると考えられる. 図 6, 図 8のグラフを見てみると，それぞれ予想した值の近傍で 最も制振効果が大きいことがわかり，実験と理論がよく 一致していると考えられよう.

\section{3 減哀の評価}

生じる電気的エネルギー $U_{\mathrm{E}}$ は, 電気機械結合係数 $k$ と，機械的エネルギー $U_{\mathrm{M}}$ を使って表すことができる.

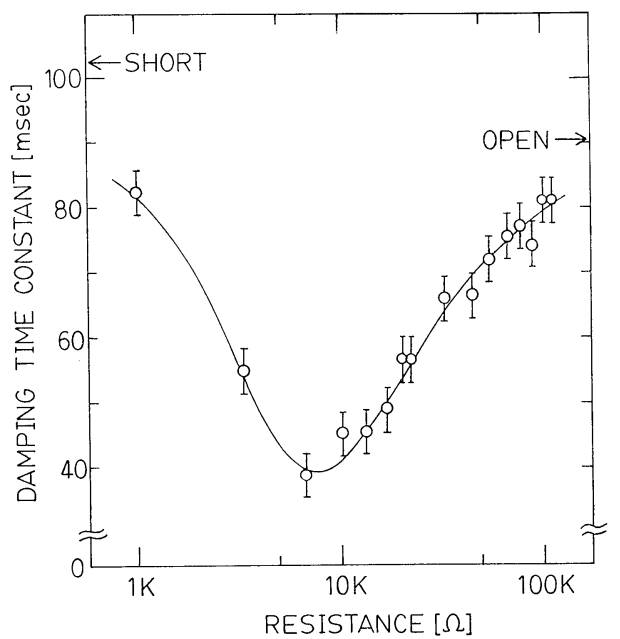

Fig. 6. Relation between damping time constant and external resistor.
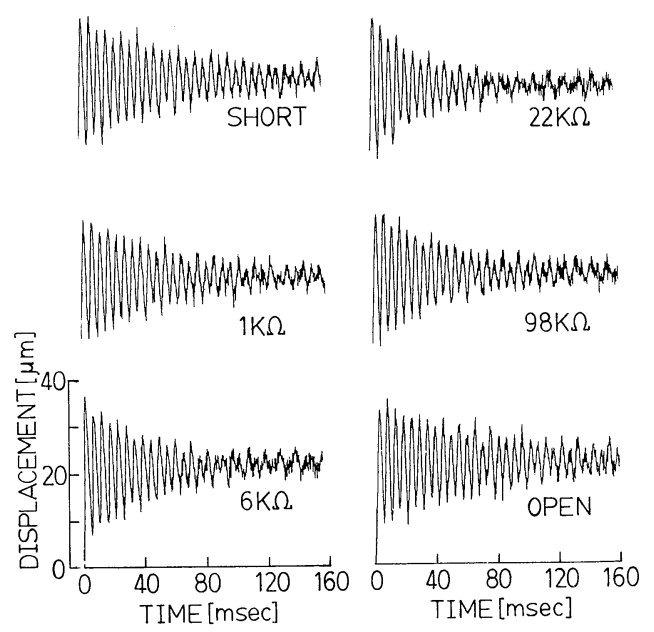

Fig. 7. Change of ringing associated with resistor change. 


$$
U_{\mathrm{E}}=U_{\mathrm{M}} \times k^{2}
$$

本研究の圧電ダンパーは抵抗 $R$ を接続することで電 気的エネルギーを熱エネルギーに変換するが，その効率 は最大 $50 \%$ であることは既に 2 章原理で説明した.よっ て, 振動の機械的エネルギ一はそれの $k^{2} / 2$ 倍が熱エネ ルギーとなって消費されるので，1回振動するたびに振 動のエネルギーは $\left(1-k^{2} / 2\right)$ 倍になる．振幅の 2 乗が エネルギーなので 1 回振動するたびに振幅は $\sqrt{1-k^{2} / 2}$ 倍になる。 そして共振周期を $T_{0}$ とすれば $t$ 秒間に 2 $t / T_{0}$ 回振動するので $t$ 秒後の振幅は

$$
\left(1-\frac{k^{2}}{2}\right)^{t / T_{0}}
$$

となる。

したがって残留振動の周期を $T_{0}$ とし, $t$ 秒後の振動 の振幅の減衰を式で表すと次のようになる.

$$
\left(1-\frac{k^{2}}{2}\right)^{t / T_{0}}=e^{-t / \tau}
$$

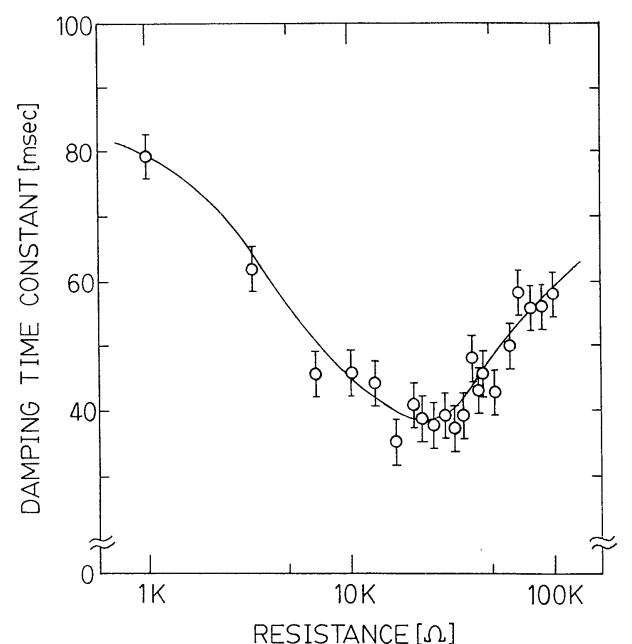

Fig. 8. Relation between damping time constant and external resistor.

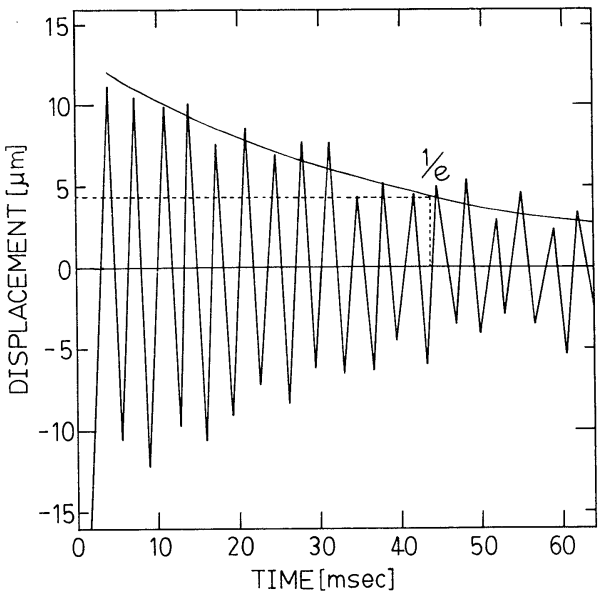

Fig. 9. Ringing of bimorph $1(R=6.6 \mathrm{k} \Omega)$.
これより, 振動減衰の時定数 $\tau$ をちえ関係式として,

$$
\tau=-\frac{T_{0}}{\ln \left(1-k^{2} / 2\right)}
$$

を得る.ここでバイモルフ 1 の測定結果を用いて減衰の 時定数を考察する.

$k=0.28, T_{0}=3.4 \mathrm{~ms}$ を代入すると, $\tau=85 \mathrm{~ms}$ となる. この $\tau$ は実験の約 $40 \mathrm{~ms}$ に比較するとかなり大きい. それは以上の取り扱いで，バイモルフが理想的に $Q_{\mathrm{M}}$ が きわめて大きな状態で全く損失がないものとしたためで ある. 実際は機械的損失を伴うので, その減衰の時定数 をショートしたときの時定数 $\tau_{s}=102 \mathrm{~ms}$ で代用する. すると全体の振動は次の式のように表される.

$$
e^{-t / \tau_{\text {total }}}=e^{-t / \tau_{s}} \times e^{-t / \tau}
$$

したがって

$$
\frac{1}{\tau_{\text {total }}}=\frac{1}{\tau_{\mathrm{s}}}+\frac{1}{\tau}
$$

を得ることができ, 各々の時定数の関係は（10）式で与 えられることがわかった。

$\tau_{\mathrm{s}}=102 \mathrm{~ms}, \tau=85 \mathrm{~ms}$ を代入すると, $\tau_{\text {total }}=46 \mathrm{~ms}$ と なり，図 9 に示されたとおりであることがわかり，実験 と一致していると考えられる.

\section{5. 総 括}

圧電セラミックスをダンパーに応用することを試み て，生じた電荷を熱エネルギーに変換するために抵抗を 持続し,減衰の時定数と抵抗の值との関係を調べた結果, 以下の事が明らかになった。

（1）圧電セラミックスは制振に非常に有効であるこ とが確認された.

（2）制振の度合（ダンピング時定数）を，接続する 抵抗を変えることにより連続的に変化させられることが わかった。

（3）制振の原理を簡単な数式を用いて説明し, 最大 の効果を得られる抵抗の值を予測して実験結果との一致 を見ることができた。

（4）更に電気機械結合係数 $k$ の值を用いることで どの程度の振動の減衰が得られるかを予測して実験結果 との一致を見ることができた。

（8）式よりわかるように，一般に減衰定数 $\tau$ を小 くするには， $T_{0}$ を小さく $k$ を大きくする必要がある. 本実験で用いたバイモルフは屈曲の振動モードを用いる タイプで, 同じ形状の圧電素子の中では最も条件の悪い ものである．横振動モ一ド $\left(k_{31}\right)$ あるいは縦振動モ一 ド $\left(k_{33}\right)$ 素子を利用すれば，より振動の娍衰は速める ことができる.

\section{文献}

1）牛腸楨男，金子洪太郎，応用物理，51，1396-97 (1982).

2) S. Sugiyama and K. Uchino, "Pulse Driven Method of 
Piezoelectric Actuators," ISAF '86 Proceedings of the Sixth IEEE, (1986) pp. 637-40

3) 神保泰雄, 古川英一, “工業振動学演習”, 学献社 (1964).

4) K. Uchino, Am. Ceram. Soc. Bull., 65, 647-52(1986).

5) 内野研二, “圧電/電歪アクチュエータ”, 森北出版 (1986).
6) K. Uchino, S. Nomura, L. E. Cross, R. E. Newnham and S. J. Jang, J. Mater. Sci., 16, 569 (1981).

7) K. Uchino and S. Nomura, Jpn. J. Appl. Phys., 20 [Suppl. 4], 225 (1981). 